\title{
PENGARUH SPREAD, MARKET VALUE, VARIANCE RETURN DAN DIVIDEND PAYOUT RATIO TERHADAP HOLDING PERIOD SAHAM
}

\author{
Ni Luh Ayu Yulita Utami ${ }^{(1)}$ \\ Ida Bagus Panji Sedana ${ }^{(2)}$ \\ ${ }^{(1),(2)}$ Fakultas Ekonomi dan Bisnis Universitas Udayana, Bali - Indonesia \\ e-mail: u.yulita@ymail.com
}

\begin{abstract}
ABSTRAK
Penelitian ini memiliki tujuan untuk mengetahui pengaruh spread, market value, variance return dan dividend payout ratio terhadap holding period saham sektor industri dasar dan kimia periode 2011-2014. Penelitian dilakukan dengan menggunakan metode observasi non partisipan, data yang digunakan berupa data sekunder yang diperoleh di Bursa Efek Indonesia (BEI) melalui situs www.idx.co.id. Sampel yang digunakan dalam penelitian sebanyak delapan perusahaan yang ditentukan dengan menggunakan metode purposive sampling. Teknik analisis yang digunakan dalam penelitian adalah Regresi Linear Berganda. Berdasarkan hasil analisis, variabel spread memiliki pengaruh negatif tidak signifikan, market value memiliki pengaruh negatif signifikan, variance return memiliki pengaruh negatif tidak signifikan dan dividend payout ratio memiliki pengeruh positif signifikan. Secara simultan variabel bebas berpengaruh signifikan terhadap holding period. Berdasarkan hasil penelitian ini hendaknya investor lebih memperhatikan variabel market value dan dividend payout ratio yang memiliki pengaruh signifikan terhadap holding period.
\end{abstract}

Kata kunci: spread, market value, variance return, dividend payout ratio, holding period

\begin{abstract}
The purpose of this study was to determine the effect spreads, market value, variance return and dividend payout ratio of the holding period of the stock chemical and basic industry sectors 2011-2014 period. The study was conducted using the method of non-participant observation, the data used is secondary data obtained in the Indonesia Stock Exchange (IDX) through the site www.idx.co.id. The sample used in the study of eight companies which were determined using purposive sampling method. The analysis technique used in this research is multiple linear regression. Based on the analysis, variable spreads had a negative influence is not significant, the market value has a significant negative effect, return variance has no significant negative effect and the dividend payout ratio has a significant positive pengeruh. Simultaneously independent variables significantly influence the holding period. Based on the results of this study should investors pay attention to the variable market value and the dividend payout ratio that has a significant influence on the holding period.
\end{abstract}

Keywords: spread, market value, variance return, dividend payout ratio, holding period

\section{PENDAHULUAN}

Investasi dewasa ini menjadi pilihan masyarakat dalam menggunakan kelebihan dananya. Menurut Tandelilin (2010:2) investasi merupakan komitmen atas sejumlah dana atau sumber daya lainnya yang dilakukan pada saat ini, dengan tujuan memperoleh keuntungan dimasa yang akan datang. Investasi dapat dilakukan pada aset riil (tanah, emas, dan bangunan) maupun pada aset finansial (surat berharga atau sekuritas). Perdagangan sekuritas di Indonesia sendiri dilakukan di Bursa Efek Indonesia (BEI). Sekuritas yang diperdagangkan di BEI merupakan salah satu bentuk investasi jangka panjang yang dapat dipilih oleh investor.

Investor memiliki kebebasan untuk memilih jenis sekuritas dalam melakukan investasi di perusahaan yang go public. Investor juga memiliki kebebasan dalam menentukan jumlah sekuritas yang mereka beli dan lamanya memegang atau menahan sekuritas tersebut. Investor yang merasa sekuritas yang mereka beli akan membawa keuntungan, maka investor tersebut akan menahan sekuritasnya dalam jangka waktu yang lebih lama atau segera melepas sekuritas tersebut jika diprediksi kurang menguntungkan. Perilaku investor yang melepas atau menahan kepemilikan sahamnya dilakukan investor untuk memaksimalkan keuntungannya atau meminimalkan risiko yang harus dihadapi. Lamanya investor menahan dananya pada sekuritas tertentu disebut dengan holding period, setiap investor memiliki analisis investasi masing-masing dalam menahan atau melepas sekuritas yang dimiliki, fenomena ini menjadi menarik untuk diteliti. 
Saham merupakan sekuritas yang diperdagangkan dipasar ekuitas yang paling dikenal oleh masyarakat Indonesia, sehingga pasar ekuitas sering dikenal sebagai pasar saham yang mengacu pada saham biasa. Perusahaan yang sudah go public akan menerbitkan saham untuk dibeli oleh masyarakat atau investor. Perusahaan yang menerbitkan saham biasa disebut dengan emiten. Investasi melalui saham akan memperoleh imbalan yang berupa dividen yang besarnya ditentukan oleh rapat umum pemegang saham (RUPS) tiap akhir periode. Menurut Wiagustini (2010:210) saham merupakan tanda penyertaan atau kepemilikan seseorang atau badan dalam suatu perusahaan. Saham dapat pula didefinisikan sebagai bukti kepemilikan atau penyertaan pasar modal investor terhadap suatu perusahaan yang akan memperoleh imbalan berupa dividen.

Saham memiliki tiga jenis nilai, antara lain: nilai buku, nilai pasar, dan nilai intrinsik. Nilai buku adalah nilai yang dihitung berdasarkan pembukuan yang dibuat oleh perusahaan yang menerbitkan saham atau emiten. Nilai pasar adalah nilai saham di pasaran, nilai pasar ini ditunjukan oleh harga saham di bursa efek. Nilai intrinsik adalah nilai saham yang seharusnya terjadi (Tandelilin, 2010:301). Saat nilai pasar saham lebih tinggi dari nilai intrinsiknya maka saham tersebut tergolong mahal atau overvalued. Jika nilai pasar saham lebih rendah dari nilai intrinsiknya saham tersebut tergolong murah atau undervalued.

Saham menjadi sekuritas yang menarik karena memiliki dua keuntungan yaitu dividen dan kenaikan harga saham (capital gain). Saham menjadi sekuritas yang paling diminati dapat dilihat dari perkembangan jumlah perusahaan yang menerbitkan saham dan volume transaksi atas saham pada Bursa Efek Indonesia. Volume transaksi yang terjadi dapat mencerminkan keputusan investor terhadap mempertahankan atau melepaskan saham yang dimiliki. Perkembangan saham dari tahun 20082014 dapat dilihat pada Tabel 1.

Tabel 1. Perkembangan Jumlah Perusahaan dan Volume Transaksi Saham di BEI Tahun 2008-2014

\begin{tabular}{ccc}
\hline Tahun & Jumlah Perusahaan & Volume Transaksi (milyar saham) \\
\hline 2008 & 396 & 787,85 \\
2009 & 398 & $1.467,66$ \\
2010 & 420 & $1.330,87$ \\
2011 & 440 & $1.203,55$ \\
2012 & 462 & $1.053,76$ \\
2013 & 483 & $1.342,66$ \\
2014 & 506 & $1.327,02$ \\
\hline
\end{tabular}

Sumber: www.ojk.go.id

Lamanya waktu yang diperlukan investor untuk berinvestasi dengan sejumlah uang yang dikeluarkan atau dapat dikatakan rata-rata dari panjangnya waktu investor menahan saham suatu perusahaan selama jangka waktu atau periode tertentu disebut holding period (Jones, 2004). Holding period dapat didefinisikan sebagai merupakan rata-rata lamanya waktu investor dalam menahan atau menyimpan saham suatu perusahaan yang dimiliki selama periode waktu tertentu.

Seorang investor yang melakukan investasi akan mendasari keputusannya dengan analisis investasi yang teliti, setiap keputusan yang diambil dilakukan dengan pertimbangan yang baik agar return yang didapatkan sesuai harapan. Ahmad (2004:89) mengatakan bahwa untuk melakukan investasi dilakukan lima analisis yaitu pertama analisis dalam mempertimbangkan tarif atau biaya transaksi (transaction cost) dapat berupa tarif pajak dan biaya komisi. Kedua, analisis mengenai jenis investasi yang dilakukan dan risiko yang ada didalamnya serta keuntungan yang akan diperoleh. Ketiga, kondisi ekonomi yang berkaitan dengan investasi yang dilakukan. Keempat, kelompok industri tempat melakukan investasi. Kelima, kinerja dari perusahaan yang akan dilakukan investasi. Analisis yang tepat tentu akan mempengaruhi lama kepemilikan saham atau holding period.

Studi mengenai faktor-faktor yang mempengaruhi holding period telah dilakukan oleh Atkins dan Dyl (1997). Penelitian ini didasarkan atas penelitian yang dilakukan oleh Amihud dan Mendelson (1986) bahwa aset dengan transaction cost yang lebih tinggi akan ditahan oleh investor dalam waktu yang lebih lama, dan sebaliknya. Penelitian ini dilakukan di saham Nasdaq periode 1983 hingga 1991 dan New York Stock Exchange (NYSE) periode 1975 hingga 1989. Penelitian tersebut menemukan bahwa holding period dipengaruhi oleh transaction cost yang tercermin 
dari bid-ask spread saham. Selain penelitian tersebut holding period dipengaruhi oleh dua faktor yaitu faktor eksternal dan faktor internal. Faktor eksternal yaitu inflasi atau keadaan perekoniman suatu negara, dan faktor internal yaitu transaction cost: bid-ask spread, market value, dan risk of return (Mendelson, 1986).Penelitian ini dilakukan untuk melakukan pengujian kembali faktor internal yang mempengaruhi holding period tehadap saham yang tercatat di Bursa Efek Indonesia.

Seorang investor yang melakukan investasi, perlu memperhatikan biaya transaksi yang efektif dan analisis yang hati-hati sehingga dapat menghasilkan return yang besar (Santoso, 2008). Biaya transaksi akan tercermin dari bid-ask spread. Bid-ask spread merupakan selisih dari harga beli tertinggi dengan harga jual terendah dari suatu saham. Bidadalah harga tertinggi yang diajukan oleh pembeli saham, dan ask adalah harga terendah yang ditawarkan oleh penjual saham (Jones, 2004:89).

Aset yang memiliki spread yang besar akan menghasilkan expected return yang lebih tinggi sehingga para investor akan lebih lama menahannya atau holding period yang dimiliki atas aset tersebut lebih panjang. Penelitian mengenai bid-ask spread dan holding period sebelumnya sudah pernah dilakukan. Menurut Santoso (2008) dan Wisayang (2009) bid-ask spred memiliki pengaruh positif signifikan terhadap holding period. Hasil penelitian tersebut berbeda dengan Arma (2013) yang menyatakan bid-ask spread memiliki pengaruh yang negatif terhadap holding period, hal ini disebabkan karena kecenderungan investor saat ini akan lebih cepat melepas saham yang memiliki bidask spread yang tinggi dengan harapan memperoleh gain yang lebih besar. Ratnasari (2014) serta Miapuspita (2003) juga menyatakan bahwa bid-ask spread memiliki pengaruh negatif signifikan terhadap holding period karena pada sampel perusahaan yang diteliti menghasilkan koefisien yang paling rendah dibanding variabel lainnya, sehingga bid-ask spread memiliki pengaruh yang kecil bagi holding period.

Market value (nilai pasar saham) merupakan variabel yang menunjukkan nilai sebuah perusahaan. Semakin besar nilai pasar suatu perusahaan maka semakin lama pula investor akan menahan kepemilikan atas saham perusahaan tersebut, atau sebaliknya jika nilai pasar perusahaan kecil maka rentang waktu investor menahan kepemilikan saham perusahaan tersebut semakin pendek. Perbedaan lamanya kepemilikan saham tersebut disebabkan karena investor menganggap perusahaan yang besar memiliki kondisi keuangan yang stabil dan laporan keuangan yang kompeten. Perusahaan besar juga cenderung memiliki stabilitas dalam distribusi return saham sehingga investor akan menahan sahamnya lebih lama. Santoso (2008) market value juga dapat menimbulkan spekulasi dikalangan investor. Perubahan kenaikan market value dapat menimbulkan return yang diharapkan berupa capital gain.

Subali dan Zuhroh (2002) menyatakan bahwa market value merupakan faktor yang paling dominan dalam menentukan lamanya kepemilikan saham (holding period). Hasil tersebut sama dengan hasil penelitian Margareta dan Diantini (2014) yang menyatakan market value memiliki hubungan yang positif dan signifikan terhadap holding period. Hasil yang berbeda disampaikan oleh Wisayang (2009), Maulina (2009) dan Peranginangin (2013) yang menyatakan bahwa market value memiliki pengaruh yang positif tidak signifikan terhadap holding period. Pengaruh yang tidak signifikan ini dikarenakan pada perusahaan sampel terjadi penambahan jumlah saham dalam jumlah besar yang direspon investor sebagai tanda bahwa perusahaan yang berangkutan sedang mengalami kesulitan keuangan, sehingga investor dengan cepat melepas kepemilikan sahamnya.

Risiko dan return selalu menjadi pertimbangan bagi investor saat menganalisis segala keputusan investasinya. Semakin besar risiko yang ditanggung oleh investor, semakin besar pula return yang diharapkan. Santoso (2008) menyatakan variance return saham adalah ukuran langsung dari volatilitas saham yang merupakan cerminan dari risiko perusahaan. Menurut Stoll dan Whaley (1983) melakukan investasi pada perusahaan yang besar memiliki risiko yang lebih besar dibanding perusahaan yang kecil, sehingga akan mempengaruhi holding period saham dan menjadikan hubungan variance return dengan holding period negatif (Atkins dan Dyl 1997). Artinya jika risiko yang dimiliki saham itu besar maka periode kepemilikan saham relatif lebih pendek dan sebaliknya semakin rendah risiko yang dimiliki saham maka periode kepemilikan saham relatif lebih panjang.

Penelitian yang dilakukan Maulina (2009), Santoso (2008) dan Perangin-angin (2013) menyatakan hubungan variance return dengan holding period saham adalah negatif signifikan. Sedangkan Ratnasari (2014) dan Murniati (2015) menyatakan variabel variance return tidak 
berpengaruh signifikan terhadap holding period. Perbedaan hasil dalam penelitian ini disebabkan oleh fluktuasi dari variance return pada sampel yang digunakan sangat kecil sehingga tidak bisa menjelaskan pengaruhnya terhadap holding period.

Selain variabel bid-ask spread, market value dan variance return, variabel lain yang diduga juga mempengaruhi keputusan investor dalam menahan kepemilikan saham suatu perusahaan adalah dividend payout ratio. Menurut Darmaji dan Fakhruddin (2012:159), dividend payout ratio merupakan perbandingan dividen per lembar saham dengan laba bersih per lembar saham yang diperoleh. Pembayaran dividen yang optimal merupakan cerminan kondisi keuangan perusahaan yang sehat, sehingga akan mempengaruhi persepsi pasar dan akan berdampak pada holding period saham perusahaan. Seorang investor melakukan investasi saham mengharapkan memperoleh return dari saham yang berupa capital gain dan dividend. Perusahaan yang memberikan dividend kepada pemegang sahamnya akan lebih diminati untuk dilakukan investasi dan memiliki holding period yang lebih panjang.

Berdasarkan penelitian yang dilakukan oleh Nurwani (2012) dividend payout ratio memiliki pengaruh positif signifikan terhadap holding period dan merupakan variabel yang koefisiennya paling tinggi. Hasil penelitiani ini bertentangan dengan Maulina (2009) yang menyatakan bahwa dividend payout ratio tidak berpengaruh signifikan terhadap holding period, hal ini disebabkan karena pada beberapa perusahaan sampel yang digunakan untuk penelitian tidak mampu membayar dividen sehingga tidak bisa menjelaskan hubungannya dengan holding period.

Informasi yang tepat sangat dibutuhkan dalam mengambil sebuah keputusan dalam berinvestasi. Misalnya saja indeks harga saham yang merupakan indikator yang mencerminkan pergerakan dari harga saham. Apabila saham pada perusahaan sektor industri dasar dan kimia pada periode tertentu lebih rendah daripada periode sebelumnya, berarti nilai investasi yang terjadi pada periode tersebut mengalami penurunan. Keputusan investasi yang dapat diambil berupa keputusan untuk membeli saham, menjual saham atau menahan saham selama periode tertentu.

Berdasarkan uraian yang sudah dijelaskan, maka penelitian ini akan meneliti mengenai pengaruh variabel bid-ask spread, market value, variance return dan dividend payout ratio terhadap holding period saham. Adapun jenis saham yang dipilih adalah saham pada sektor industri dasar dan kimia karena saham pada sektor industri dasar dan kimia memiliki market share yang besar di pasar modal.

Spread merupakan proksi dari transaction cost atau biaya yang timbul akibat dari transaksi saham. Spread juga merupakan akibat dari asimetri informasi yang terjadi di pasar modal akibat dari persaingan yang tinggi antar emiten. Saham yang memiliki spread yang tinggi akan dipertahankan lebih lama oleh investor, hal ini terjadi karena investor memgharapkan keuntungan yang lebih tinggi dan mengurangi risiko. Fenomena ini menyebabkan spread memiliki pengaruh yang searah dengan holding period.

Penelitian sebelumnya oleh Demsetz dalam Maulina (2009) yang menguji mengenai pentingnya bid-ask spread terhadap keputusan investasi dengan menghubungkan spread dengan transaction cost mengatakan bahwa aset yang memiliki spread yang besar akan menghasilkan expected return yang tinggi pula. Investor akan mengharapkan memperoleh net return yang lebih besar dengan menahan saham yang memiliki spread yang tinggi.

Penelitian yang dilakukan oleh Atkins dan Dyl (1997) mengenai bid-ask spread menemukan bahwa bid-ask spread memiliki pengaruh positif dan signifikan terhadap holding period. Analisis yang dilakukan oleh Chung dan Wei (2005) menyimpulkan bahwa bid-ask spread yang merupakan fungsi dari transaction cost merupakan variabel dominan yang mempengaruhi holding period saham. Berdasarkan penelitian tersebut dapat disimpulkan seorang investor yang membeli sahamnya dengan harga tinggi cenderung akan menahan sahamnya dalam waktu yang lebih lama, dengan harapan harga jual sahamnya akan lebih tinggi dimasa mendatang. Penelitian ini memiliki tujuan untuk mengetahui pengaruh secara pasial dari spread, market value, variance return dan dividend payout ratio terhadap holding period saham sektor industri dasar dan kimia periode 2011-2014.

Penelitian lainnya disampaikan oleh Maulina (2009), Hadi (2008), Wisayang (2010) dan Santoso (2008) yang menyatakan pengaruh bid-ask spread adalah positif dan signifikan terhadap holding period. Transaction cost yang terjadi akibat perdagangan saham memiliki pengaruh yang searah terhadap holding period saham, sehingga saham yang memiliki transaction cost yang tinggi akan ditahan kepemilikannya lebih lama oleh investor. Berdasarkan teori dan penelitian terdahulu, maka hipotesis dalam penelitian adalah sebagai berikut: 
$\mathrm{H}_{1}$ : Spread berpengaruh positif dan signifikan terhadap holding period saham sektor industri dasar dan kimia di BEI.

Investor menggunakan market value sebagai ukuran dari suatu perusahaan, dimana perusahaan yang besar memiliki market value yang besar pula. Saham perusahaan yang memiliki market value yang besar lebih menarik bagi investor karena perusahaan dianggap memiliki kondisi keuangan yang lebih stabil dan memiliki akses yang mudah di pasar modal. Estimasi tersebut menyebabkan saham perusahaan yang memiliki market value yang besar cenderung memiliki holding period yang lebih lama.

Fama (1993) menyatakan bahwa market value atau ukuran perusahaan berkaitan dengan profitabilitas perusahaan. Perusahaan besar dianggap memiliki profitabilitas yang tinggi sehingga investor lebih tertarik berinvestasi pada perusahaan tersebut. Berdasarkan penelitian sebelumnya dapat disimpulkan bahwa semakin besar market value suatu perusahaan maka semakin lama pula investor menahan sahamnya karena asumsi perusahaan besar memiliki profitabilitas yang tinggi dan stabil.

Penelitian mengenai hubungan market value dengan holding period yang dilakukan oleh Margareta (2015) menyatakan bahwa market value memiliki hubungan yang positif dan signifikan terhadap holding period. Koefisien dari market value merupakan variabel yang paling dominan berpengaruh terhadap holding period. Pernyataan ini didukung oleh penelitian sebelumnya yaitu oleh Ratnasari (2014), Arma (2013), dan Wisayang (2009) yang menyatakan bahwa market value memiliki hubungan searah atau positif dan signifikan terhadap holding period. Berdasarkan teori dan penelitian terdahulu, maka hipotesis dalam penelitian adalah sebagai berikut:

$\mathrm{H}_{2}$ : Market value berpengaruh positif dan signifikan terhadap holding period saham sektor industri dasar dan kimia di BEI.

Hubungan return dengan risiko adalah hubungan yang searah atau linier, artinya semakin tinggi risiko yang ditanggung semakin tinggi pula return yang diharapkan. Perkembangan variance return saham yang tinggi akan menyebabkan holding period menjadi lebih pendek karena investor telah mendapatkan keuntungan sesuai dengan yang diharapkan.

Arma (2013) menyimpulkan bahwa variance return memiliki pengaruh negatif yang signifikan terhadap holding period. Hal ini berkaitan dengan analisis investor terhadap risiko yang mungkin dihadapinya karena variance return merupakan proksi dari risiko perusahaan. Seorang yang memperhatikan risiko dalam berinvestasi akan memperhatikan variance return suatu perusahaan, jika variance return meningkat maka holding period akan menurun.

Penelitian yang dilakukan oleh Perangin-angin (2013) menyimpulkan bahwa variabel variance return merupakan variabel yang paling berpengaruh terhadap holding period saham sektor pertambangan periode 2009 hingga 2011. Hal ini menunjukkan bahwa investor akan menahan sahamnya lebih pendek pada perusahaan yang memiliki variance return yang tinggi. Menurut Santoso (2008) variance return memiliki pengaruh yang negatif dan signifikan terhadap holding period. Berdasarkan teori dan penelitian terdahulu, maka hipotesis dalam penelitian adalah sebagai berikut:

$\mathrm{H}_{3}$ : Variance return berpengaruh negatif dan signifikan terhadap holding period saham sektor industri dasar dan kimia di BEI.

Perusahaan yang membagikan dividen umumnya lebih menarik bagi seorang investor daripada peusahaan yang tidak membagikan dividen. Hal ini menyebabkan investor diharapkan mau memegang atau menahan kepemilikan sahamnya dalam waktu yang lebih lama. Perusahaan akan berusaha membayar dividen kepada pemegang saham dengan tepat waktu dan tidak mengurangi jumlahnya. Pengurangan jumlah dividen yang dibagikan dapat ditangkap sebagai sinyal negatif oleh pemegang saham karena perusahaan dianggap mengalami kesulitan likuiditas (Hartono, 2013:164).

Bagi perusahaan pembayaran dividen merupakan alat komunikasi langsung kepada pasar mengenai ekonomi perusahaan. Sehingga saham perusahaan yang membagikan dividen akan lebih diminati oleh investor dan kepemilikan atas sahamnya akan ditahan lebih lama. Maulina (2009) menyatakan faktor motif pembelian saham merupakan hal utama yang dipertimbangkan investor, dimana investor mengharapkan memperoleh pendapatan dari dividen. Maka keputusan perusahaan untuk membagikan dividen merupakan kebijakan yang memiliki pengaruh yang besar terhadap harga saham perusahaan di pasar modal.

Menurut Nurwani (2012) dividend payout ratio memiliki hubungan yang positif dan signifikan terhadap holding period. Seorang investor yang memiliki orientasi jangka panjang tentunya mengharapkan memperoleh return atas investasi yang dilakukan yang berupa capital gain dan dividend. Penelitian yang dilakukan oleh 
Kusumayanti (2015) dan Murniati (2015) menyimpulkan bahwa dividend payout ratio memiliki pengaruh positif dan signifikan terhadap holding period saham. Berdasarkan teori dan penelitian terdahulu, maka hipotesis dalam penelitian ini adalah sebagai berikut:

$\mathrm{H}_{4}$ : Dividend payout ratio berpengaruh positif dan signifikan terhadap holding period saham sektor industri dasar dan kimia di BEI.

\section{METODE}

Penelitian yang dilakukan adalah untuk mengetahui pengaruh atau hubungan antara variabel bebas dengan variabel terikat, sehingga dapat digolongkan sebagai penelitian asosiatif. Menurut Sugiyono (2012:36) penelitian asosiatif merupakan penetian yang mencari pengaruh suatu variabel bebas terhadap variabel terikat. Adapun desain penelitian dalam penelitian ini adalah sebagai berikut:

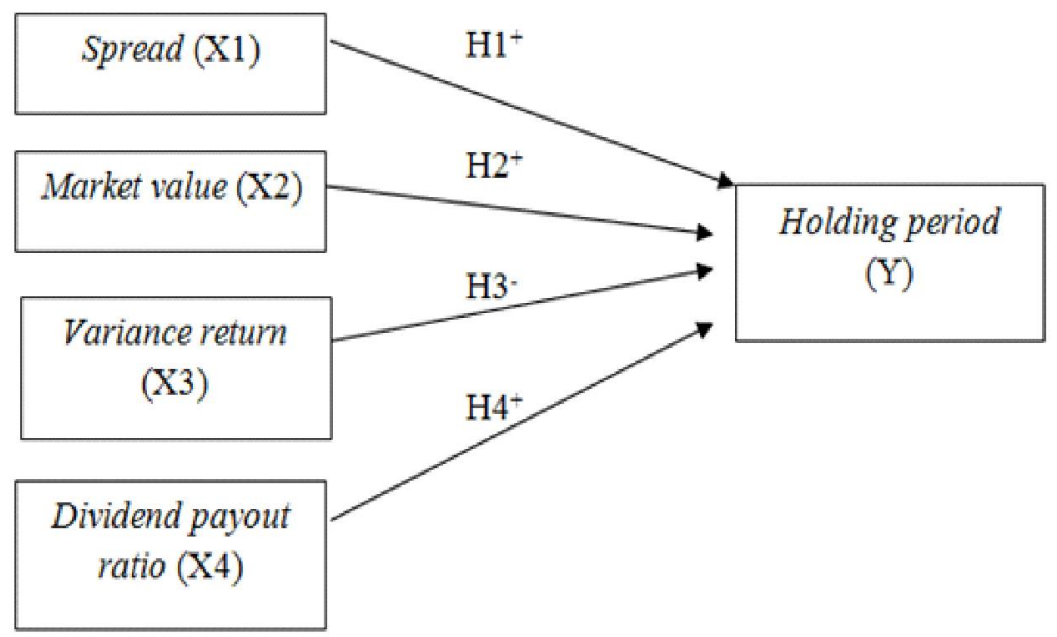

\section{Gambar 1. Desain Penelitian}

Lokasi dan ruang lingkup dalam penelitian ini adalah saham perusahaan sektor industri dasar dan kimia di BEI periode 2011 hingga 2014. Lokasi ini dipilih karena perusahaan sektor industri dasar dan kimia merupakan salah satu sektor dari perusahaan manufaktur yang memiliki kapitalisasi yang besar, sehingga saham perusahaan sektor industri dasar dan kimia tergolong salah satu sektor yang memiliki kinerja baik. Saham peruhasaan dengan kapitalisasi yang tinggi cenderung lebih diminati oleh investor sehingga fenomena holding period dapat dengan mudah dijelaskan. Objek penelitian dalam penelitian ini adalah holding period atau lamanya seorang investor memiliki atau menahan suatu saham sektor industri dasar dan kimia pada periode 2011 hingga 2014 di BEI.

Variabel dependen atau variabel terikat merupakan variabel yang dipengaruhi atau variabel yang menjadi akibat dari adanya variabel bebas. Sering disebut sebagai variabel output, kriteria, atau konsekuen. Variabel terikat dalam penelitian ini adalah holding period. Holding period adalah lamanya waktu yang diperlukan seorang investor dalam berinvestasi dengan sejumlah uang yang bersedia dikeluarkan. Holding period akan diukur dengan holding period selama periode 2011 hingga
2014 menggunakan satuan hari. Rata-rata holding period tiap tahun dapat dihitung dengan membagi jumlah saham yang beredar dengan volume perdagangan saham $i$ pada tahun ke $t$.

Variabel independen atau variabel bebas merupakan variabel yang tidak tergantung dan tidak dipengaruhi oleh variabel lain atau variabel yang menjadi sebab timbulnya variabel terikat. Variabel bebas dalam penelitian ini adalah spread (X1), market value (X2), variance return (X3), dan dividend payout ratio (X4). Untuk menghitung spread dilakukan dengan membuat rata-rata bidask spread bulanan untuk tiap saham yang diteliti selama periode 2011 hingga 2014 dalam bentuk rasio.Market value adalah cerminan dari ukuran suatu perusahaan atau nilai sebenarnya dari aktiva perusahaan yang terlihat di pasar (Santoso, 2008). Market value menunjukkan ukuran suatu perusahaan atau merupakan nilai sebenarnya dari aktiva perusahaan yang direfleksikan di pasar. Semakin besar ukuran suatu perusahaan berarti semakin besar pula market value perusahaan tersebut. Market value diukur menggunakan market value selama periode 2011 hingga 2014 dengan satuan rupiah (Rp). Risiko perusahaan yang diproksikan oleh variance return yang diukur 
menggunakan rumus variance return selama periode 2011 hingga 2014 dalam bentuk rasio.Kebijakan dalam membagikan dividen lebih menarik bagi investor karena perusahaan dianggap memiliki kondisi keuangan yang stabil dan mampu memperoleh laba tiap periode. Dividend payout ratio diukur dengan Dividend payout ratio selama periode 2011 hingga 2014 dengan satuan persentase (\%). Menurut Darmadji dan Fakhrudin (2012:159) dividend payout ratio merupakan persentase dari perbandingan dividen per lembar saham yang telah dibayar pada tahun tersebut dengan laba per lembar saham pada akhir tahun.

Data menurut sifatnya yang digunakan dalam penelitian ini adalah data kuantitatif. Data kuantitatif adalah data yang berupa angka atau data kualitatif yang diangkakan (Sugiyono, 2012:14). Data kuantitatif yang digunakan dalam penelitian ini adalah data berupa angka mengenai bid price dan ask price, volume transaksi, jumlah saham yang beredar, harga saham saat penutupan dan harga saham sebelumnya. Data menurut sumbernya yang digunakan pada penelitian ini adalah sumber data sekunder yang meliputi data-data bid price dan ask price, volume transaksi, jumlah saham yang beredar, harga saham saat penutupan dan harga saham sebelumnya. Data-data tersebut diperoleh dari http/ /:www.idx.co.id dan Indonesian Capital Market Directory yang dikumpulkan dari Januari 2011 hingga Desember 2014.

Populasi adalah wilayah generalisasi yang terdiri atas obyek/subyek penelitian yang memiliki karakteristik dan kualitas tertentu yang ditetapkan oleh peneliti (Sugiyono, 2013:115). Populasi dalam penelitian ini adalah seluruh perusahaan sektor industri dasar dan kimia di BEI. Sampel adalah sebagian dari jumlah dan karakteristik yang dimiliki oleh populasi yang dapat mewakili populasi tersebut (Sugiyono, 2013:116). Sampel dalam penelitian ini ditentukan dengan menggunakan metode purposive sampling yaitu penentuan sampel dengan terlebih dahulu menentukan kriteria-kriteria yang diinginkan.

Teknik pengumpulan data dalam penelitian ini dilakukan dengan teknik observasi non partisipan. Observasi non partisipan yang dilakukan adalah dengan mengumpulkan semua data sekunder yang dipublikasikan dan diperlukan dalam penelitian ini oleh http//:www.idx.co.id dan Indonesian Capital Market Directory selama periode 2011-2014.

Analisis yang digunakan untuk menyelesaikan permasalahan dalam penelitian ini adalah Regresi Linear Berganda. Analisis regresi linear berganda ini akan dihitung dengan bantuan SPSS for windows. Adapun persamaan linear berganda yang digunakan dalam penelitian ini adalah (Wirawan, 2002:267):

$\mathrm{Y}=\mathrm{a}+\mathrm{b}_{1} \mathrm{x}_{1}+\mathrm{b}_{2} \mathrm{x}_{2}+\mathrm{b}_{3} \mathrm{x}_{3}+\mathrm{b}_{4} \mathrm{x}_{4}+\mathrm{e}_{\mathrm{i}} \ldots \ldots \ldots \ldots \ldots$ (1) Keterangan:

$\mathrm{Y}=$ Holding period saham perusahaan manufaktur di BEI

$\mathrm{X} 1=$ Spread

$\mathrm{X} 2=$ Market value

$\mathrm{X} 3=$ Variance return

$\mathrm{X} 4=$ Dividend payout ratio

$\mathrm{a}=$ Bilangan konstanta

b1-b4 = Koefisien regresi

ei $\quad=$ Variabel pengganggu (residual error)

Uji asumsi klasik meliputi uji multikolinearitas, uji heteroskedastis, dan uji autokorelasi. Multikolonearitas dalan suatu model regresi dapat dilihat dari cut off nilai tolerance atau Variance Information Factor (VIF). Apabila nilai tolerance> 0,10 atau nilai $\mathrm{VIF}<10$, maka dapat dikatakan tidak ada gejala multikolinearitas. Pengujian heterokeskedastis dapat dilakukan dengan metode glejser, jika probabilitas signifikan $>0,05$ maka model dalam penelitian tidak terjadi heteroskedastis. Uji Autokolerasi dilakukan dengan menggunajan uji Runs Test. Hasil uji Runs Test yang menyatakan bebas autokorelasi adalah yang memiliki hasil yang lebih tinggi dari tingkat signifikansi $(\alpha)$.

Koefisien determinasi $\left(\mathrm{R}^{2}\right)$ memiliki tujuan untuk menerangkan seberapa jauh kemampuan dari variabel dependen dalam mempengaruhi variabel independen. Koefisien determinasi $\left(\mathrm{R}^{2}\right)$ memiliki rentang nilai 0 hingga 1 , semakin kecil nilai dari koefisien determinasi $\left(\mathrm{R}^{2}\right)$ yang dihasilkan berarti variasi dari variabel dependen memiliki pengaruh yang kecil terhadap variabel independen, dan sebaliknya.

Hipotesis dalam penelitian ini akan diuji meggunakan uji parsial atau uji t untuk mengetahui apakan variabel independen dalam penelitian secara parsial berpengaruh terhadap variabel dependen. Pada uji parsial akan digunakan tingkat kepercayaan sebesar 95\% atau alpha 5\%. Kriteria pengujian adalah sebagai berikut, apabila tingkat signifikansi $<5 \%$, maka hipotesis penelitian diterima dan apabila tingkat signifikansi $>5 \%$, maka hipotesis penelitian ditolak.

\section{HASIL DAN PEMBAHASAN}

Penelitian ini dianalisis menggunakan Regresi Linier Berganda, analisis ini dilakukan dengan menggunakan software SPSS 13.0 dan mendapatkan hasil sebagai berikut: 
Tabel 2. Hasil Analisis Regresi Linier Berganda Perusahaan Sektor Industri Dasar dan Kimia

\begin{tabular}{|c|c|c|c|c|c|c|}
\hline \multirow[b]{2}{*}{ Mod } & & \multicolumn{2}{|c|}{$\begin{array}{l}\text { Unstandardized } \\
\text { Coefficients }\end{array}$} & \multirow{2}{*}{$\begin{array}{c}\begin{array}{c}\text { Standardized } \\
\text { Coefficients }\end{array} \\
\text { Beta }\end{array}$} & \multirow[b]{2}{*}{$\mathrm{t}$} & \multirow[b]{2}{*}{ Sig. } \\
\hline & & $\mathrm{B}$ & Std. Error & & & \\
\hline \multirow[t]{5}{*}{1} & (Constant) & 3,426 & ,633 & & 5,411 &, 000 \\
\hline & BAS &,- 417 & ,707 &,- 143 &,- 590 & ,560 \\
\hline & LnMV &,- 235 & ,079 &,- 503 & $-2,961$ & ,006 \\
\hline & VR & $-1,449$ & ,759 &,- 492 & $-1,910$ & ,067 \\
\hline & DPR & ,410 & 447 & , 144 & 918 & ,007 \\
\hline
\end{tabular}

Sumber: data sekunder diolah, (2015)

Uji ketepatan model digunakan untuk menguji kelayakan suatu model regresi dalam penelitian. Hasil uji F pada penelitian ini adalah sebagai berikut:

Berdasarkan hasil pengolahan diperoleh nilai Sig. 0,009 < alpha 0,05 sehingga dapat disimpulkan bahwa model ini layak digunakan dalam penelitian. Hasil uji $\mathrm{F}$ juga menyatakan bahwa ada pengaruh antara variabel bebas yaitu spread, market value, variance return dan dividend payout ratio berpengaruh secara simultan terhadap variabel terikat yaitu holding period.

Berdasarkan hasil pengolahan nilai koefisien determinasi (Adjusted $R$ Square) adalah 0,295. Nilai koefisien determinasi 0,295 memiliki arti variasi dari variabel dependen yaitu spread, market value, variance return dan dividend payout ratio memiliki pengaruh sebesar 0,295 atau $29,5 \%$ terhadap variabel independen yaitu holding period, sedangkan sebesar $70,5 \%$ dipengaruhi oleh variabel lain diluar penelitian.

Berdasarkan hasil pengolahan diperoleh hasil variabel market value memiliki koefisien -0,503 dan Sig. 0,006 < alpha 0,05 sehingga dapat disimpulkan bahwa market value memiliki pengaruh yang negatif dan signifikan terhadap holding period saham perusahaan sektor industri dasar dan kimia.

Berdasarkan hasil pengolahan diperoleh hasil variabel variance return memiliki koefisien $-0,492$ dan Sig. 0,067 > alpha 0,05 sehingga dapat disimpulkan bahwa variance return memiliki pengaruh yang negatif dan tidak signifikan terhadap holding period saham perusahaan sektor industri dasar dan kimia.

Berdasarkan hasil pengolahan diperoleh hasil variabel dividend payout ratio memiliki koefisien 0,144 dan Sig. 0,007 < alpha 0,05 sehingga dapat disimpulkan bahwa dividend payout ratio memiliki pengaruh yang positif dan signifikan terhadap holding period saham perusahaan sektor industri dasar dan kimia

Berdasarkan hasil pengolahan data variabel spread memiliki koefisien -0,143 dan Sig. 0,560 > alpha 0,05 sehingga variabel spread memiliki pengaruh yang negatif dan tidak signifikan terhadap holding period saham perusahaan sektor industri dasar dan kimia dengan asumsi variabel lain adalah konstan. Hasil penelitian ini berbeda dari penelitian yang dilakukan oleh Atkins dan Dyl (1997), Santoso (2008), Wisayang (2009) dan Maulina (2009) yang menyatakan bahwa spread memiliki pengaruh yang positif dan signifikan. Hasil penelitian sesuai dengan penelitian yang dilakukan oleh Miapuspita (2003) dan Ratnasari (2014) yang menyatakan bahwa spread memiliki pengaruh negatif terhadap holding period.

Spread mewakili transaction cost yang terjadi dari transaksi saham spread yang terjadi di pasar modal disebabkan oleh faktor informasi yang tidak seimbang di pasar modal dan persaingan yang terjadi antar pelaku pasar. Semakin tidak seimbang informasi yang terjadi maka investor akan melakukan spekulasi terhadap harga saham sehingga spread akan semakin besar dan persaingan yang semakin kuat akan menyebabkan harga jual makin rendah dan harga beli makin tinggi.

Pengaruh spread yang negatif terhadap holding period saham perusahaan sektor industri dasar dan kimia disebabkan karena keinginan investor untuk memperoleh capital gain. Spread yang tinggi akan membuat investor melepas kepemilikan sahamnya agar memperoleh keuntungan dan mengurangi risiko. Beberapa perusahaan sample yang digunakan dalam penelitian merupakan perusahaan yang memiliki kinerja saham yang baik dan tergolong likuid sehingga investor akan berusaha memperoleh return yang maksimal melalui spread dari saham. 
Berdasarkan hasil pengolahan data variabel market value memiliki koefisien -0,503 dan Sig. $0,006<$ alpha 0,05 sehingga dapat disimpulkan bahwa market value memiliki pengaruh yang negatif dan signifikan terhadap holding period saham perusahaan sektor industri dasar dan kimia dengan asumsi variabel lain adalah konstan. Hasil penelitian ini tidak sama dengan penelitian yang dilakukan Atkins \& Dyl (1997), Margareta dan Diantini (2014), Hadi (2008) serta Ratnasari dan Astuti (2014) yang menyatakan bahwa market value memiliki pengaruh yang positif dan signifikan. Penelitian ini searah dengan penelitian yang dilakukan oleh Sakir dan Nurhalis (2010) yang menyatakan bahwa market value memiliki pengaruh yang negatif terhadap holding period.

Investor akan memilih perusahaan yang memiliki kondisi keuangan yang baik untuk melakukan investasi. Keuangan perusahaan yang baik dapat dilihat dari market value yang dicerminkan dari harga saham. Market value dalam penelitian ini yang bernilai negatif disebabkan oleh harga saham memiliki kecenderung akan naik hingga tingkat harga tertentu dan kembali mengalami penurunan. Saham yang diprediksi investor telah memiliki harga maksimal akan lebih cepat dilepas kepemilikannya karena dirasa akan kembali mengalami penurunan harga, kemudian kembali melakukan investasi pada saham yang dirasa harganya akan naik.

Berdasarkan hasil pengolahan data variabel variance return memiliki koefisien -0,492 dan Sig. $0,067>$ alpha 0,05 sehingga dapat disimpulkan bahwa variance return memiliki pengaruh yang negatif dan tidak signifikan terhadap holding period saham perusahaan sektor industri dasar dan kimia dengan asumsi variabel lain adalah konstan. Hasil penelitian ini tidak sejalan dengan penelitian yang dilakukan oleh Atkins \& Dyl (1997), Maulina (2009), Santoso (2008) dan Perangin-angin (2013) yang menyatakan bahwa variance renturn memiliki pengaruh yang negatif dan signifikan. Hasil penelitian ini sama dengan penelitian yang dilakukan oleh Ratnasari (2014) dan Murniati (2015) yang menyatakan bahwa variance return memiliki pengaruh negatif tidak signifikan terhadap holding period.

Variance return mewakili risiko yang akan dihadapi dalam melakukan investasi. Variance return diukur menggunakan harga penutupan pada bulan ke t dan bulan ke t-1. Dalam melakukan investasinya seorang investor akan menghindari risiko yang mungkin muncul di dalamnya, begitu pula terhadap investasi saham. Semakin tinggi risiko yang dimiliki suatu saham maka kepemilikan akan saham tersebut akan semakin pendek. Hal ini dilakukan investor untuk memastikan return dari investasinya selalu positif.

Variabel variance return dalam penelitian ini yang tidak berpengaruh signifikan disebabkan oleh perilaku investor dalam investasi saham adalah untuk memperoleh capital gain atau keuntungan atas selisih harga saham saat dijual dan dibeli. Saham yang memiliki nilai tinggi juga memiliki risiko yang tinggi, walaupun saham memiliki risiko tinggi tetap akan dibeli oleh investor, sehingga variabel variance return dalam penelitian ini kurang diperhatikan oleh investor.

Berdasarkan hasil pengolahan data variabel dividend payout ratio memiliki koefisien 0,144 dan Sig. 0,007 < alpha 0,05 sehingga dapat disimpulkan bahwa dividend payout ratio memiliki pengaruh yang positif dan signifikan terhadap holding period saham perusahaan sektor industri dasar dan kimia dengan asumsi variabel lain adalah konstan. Hasil penelitian ini sejalan dengan penelitian yang dilakukan oleh Nurwani (2012), Murniati (2015), dan Kusumayanti (2015) yang menyatakan bahwa bahwa dividend payout ratio memiliki pengaruh yang positif dan signifikan terhadap holding period saham.

Investasi yang dilakukan mengharapkan keuntungan dikemudian hari, begitu pula investasi pada saham. Saham memiliki imbalan berupa dividen kepada pemegang sahamnya, besarnya imbalan berbeda-beda tergantung dari kebijakan perusahaan. Variabel dividen payout ratio menjadi salah satu variabel yang akan dipertimbangkan oleh investor dalam menahan atau melepaskan kepemilikan sahamnya. Semakin besar presentase dari dividen payout ratio maka akan semakin menguntungkan investor, sehingga memiliki holding period yang lebih lama dan sebaliknya.

\section{SIMPULAN DAN SARAN}

Berdasarkan hasil penelitian diperoleh kesimpulan bahwa spread memiliki pengaruh negatif tidak signifikan terhadap holding period saham perusahaan sektor industri dasar dan kimia periode 2011-2014. Market value memiliki pengaruh yang negatif dan signifikan terhadap holding period saham perusahaan sektor industri dasar dan kimia. Variance return memiliki pengaruh yang negatif dan tidak signifikan terhadap holding period saham perusahaan sektor industri dasar dan kimia. 
Dividend payout ratio memiliki pengaruh yang positif dan signifikan terhadap holding period saham perusahaan sektor industri dasar dan kimia.

Berdasarkan simpulan diatas maka sara yang dapat diberikan adalah bagi investor yang akan berinvestasi pada sektor industri dasar dan kimia hendaknya lebih memperhatikan variabel market value dan dividend payout ratio yang memiliki pengaruh signifikan terhadap holding period saham sektor industri dasar dan kimia. Penelitian selanjutnya dengan topik sejenis sebaiknya dilakukan pada sektor lainnya di Bursa Efek Indonesia tidak terbatas pada sektor industri dasar dan kimia saja agar terjadi variasi hasil penelitian pada sektorsektor lainnya dan memilih sektor yang memiliki kapitalisasi yang besar. Penelitian selanjutnya dengan topik sejenis sebaiknya dilakukan dengan periode yang lebih lama karena investasi pada bursa efek indonesia tergolong investasi jangka panjang dan holding period akan lebih mudah diteliti.

\section{REFERENSI}

Ahmad, Kamirudin. 2004. Dasar-Dasar Manajemen Investasi dan Portofolio. Jakarta: Rineka Cipta

Amihud, Y. And Mendelson, H. 1986. Asset pricing and the bid-ask spread. Journal of Financial Economics. 17 (2): 223-249

Arma, Visita Yales. 2013. Faktor Penentu Holding Period Saham LQ-45 Di Bursa Efek Indonesia. Journal of Business and Banking, 3 (2): 201-212.

Atkins, A.B., and Edward, A. Dyl. 1997. Transaction Cost and Holding Period for Common Stock. Journal of Finance, 3 (1): 309-325.

Chung, S., dan Wei, P. 2005. The Relationship Between Bid-Ask Spread and Holding Periods. Global Finance Journal, (15): 239-249.

Darmadji, Tjiptono dan Hendy M Fakhrudin. 2012. Pasar Modal Indonesia: Pendekatan tanya jawab. Jakarta: Salemba Empat

Fama, E.F., and Kenneth R.F. 1993. Common Risk Factor in The Return on Stock and Bond. Journal of Finance Economics, (33): 3-56.

Hadi, Helmy Yulianto. 2008. Analisis Pengaruh BidAsk Spread, Market Value, Dan Resiko Saham Terhadap Holding Period (Studi kasus pada saham-saham LQ45 periode 2003-2005). Tesis Program Studi Magister Manajemen Program Pasca Sarjana Universitas Diponegoro, Semarang.
Hartono, Jogiyanto. 2013. Teori Portofolio dan Analisis Investasi. Edisi Kedelapan. Yogyakarta: BPFE

Jones, Charles P. 2004. Investment Analysis and Management. Ninth Edition. USA: John Wiley dan Sons Inc.

Kusumayanti, Dira. 2015. Pengaruh Bid-Ask Spread, Market Value, Variance of Return dan Dividend Payout Ratio terhadap Holding Period Saham Pada Perusahaan Manufaktur yang Terdaftar di BEI Periode 2011-2013. Skripsi Fakultas Ekonomi Universitas Negeri Yogyakarta.

Margareta, Kadek Aryati dan Ni Nyoman Ayu Diantini. 2015. Variabel-Variabel Penentu Holding Period Saham. JurnalManajemen, Strategi Bisnis dan Kewirausahaan , 9 (1): 57-64.

Maulina, Vinus., dan M. Syafi'i Idrus. 2012. Informasi Asimetri dan Periode Kepemilikan Saham Lq 45 di Bursa Efek Indonesia. Jurnal Aplikasi Manajemen, 10 (4): 741-752.

Miapuspita, Y. A. 2003. Analisis Pengaruh Bid Ask Spread, Market Value, dan Risk of Return Saham Terhadap Holding Period pada Saham Teraktif yang Tercatat di Bursa Efek Jakarta Periode 2001-2002. Jurnal Ventura, 6 (2): 117 125.

Murniati, Irma. 2015. Pengaruh Market Value, Variance Return, dan Dividend Payout Ratio Terhadap Holding Period Saham Perusahaan yang Tercatat di Indeks LQ45. Skripsi Fakultas Ekonomi Universitas Negeri Yogyakarta.

Nurwani, Dinar Ayu., Moch. Dzulkirom AR., dan Topowijono. 2012. Pengaruh Bid-Ask Spread, Market Value, Risk Of Return, Dan Dividend Payout Ratio Terhadap Holding Period Saham Biasa. Jurnal. Fakultas Ilmu Administrasi Universitas Brawijaya, Malang.

Perangin-angin, Novita Selvia M. 2013. Analisis Pengaruh Bid-Ask Spread, Maket Value dan Variance Return Terhadap Holding Period Saham Sektor Pertambangan. Jurnal Ekonomi dan Keuangan, 1 (3): 154-167.

Ratnasari, Desy dan Dewi Astuti. 2014. Pengaruh Bid Ask Spread, Market Value, dan Variance Return Terhadap Holding Period. Jurnal Finesta, 2 (1): 99-102.

Santoso, Eko Budi. 2008. Analisis Pengaruh Transaction Cost Terhadap Holding Period Saham Biasa. Jurnal Riset Akuntansi dan Keuangan, 4 (2): 116-131. 
Stoll, Hans R. Dan Robert Whaley. 1983. Transaction Cost and The Small Firm Effect. Journal of Financial Economics, (12): 57-80.

Subali dan Diana Zuhroh. 2002. Analisis Pengaruh Transaction Cost terhadap Holding Period Saham Biasa. Jurnal Riset Akuntansi Indonesia, (5): 193-213

Sugiyono. 2012. Metode Penelitian Bisnis. Bandung: Alfabeta . 2013. Metode Penelitian Bisnis. Bandung: Alfabeta

Tandelilin, Eduardus. 2010. Portofolio dan Investasi. Yogyakarta: Kanisius
Wiagustini, Ni Luh Putu. 2010. Dasar-dasar Manajemen Keuangan. Denpasar: Udayana University Press.

Wirawan, Nata. 2002. Cara Mudah Memahami Statistik 2 (Statistik Inferensia). Edisi kedua. Keraras Emas. Denpasar.

Wisayang, Vinsensia Retno Widi. 2009. Analisis Pengaruh Bid-Ask Spread, Market Value, Dan Varian Return Saham Terhadap Holding Period Pada Saham LQ 45. Jurnal. Magister Manajemen Universitas Diponegoro, Semarang. 